\title{
Image and Counter-Image: The Place of Salazarist Images of National Identity in Contemporary Portuguese Visual Culture
}

\author{
Ellen W. Sapega
}

\begin{abstract}
Neste artigo, sirvo-me de teorias da cultura visual para examinar a construção e a recepção de alguns conhecidos monumentos da arquitectura e da arte pública em Portugal que datam das primeiras décadas do regime de António de Oliveira Salazar. Depois de demonstrar como a concepção destes projectos reflecte os valores ideológicos e estéticos da época, procuro, na segunda parte do artigo, documentar a continuada importância de algumas destas construções no imaginário colectivo do país. Nesta última instância, os monumentos surgem em novos contextos que possibiltam novas interpretações do seu conteúdo cultural, interpretações estas que, às vezes, pouco ou nada têm a ver com a intenção original dos seus criadores.
\end{abstract}

The first decades of the regime of António de Oliveira Salazar present a useful and interesting starting point for the study of visual culture in twentieth century Portugal. During this period, the State actively sponsored a wide range of activities aimed at both memorializing the national past and drawing attention to the regime's perceived successes. Events such as the Portuguese Colonial Exposition, held in Oporto in 1934, the Commemoration of Year X of the National Revolution, celebrated throughout the country in 1936, and the 1940 Exposition of the Portuguese World performed the dual purpose of fostering urban renewal and providing opportunities for new development. ${ }^{1}$ At the same time, the government also undertook many other ambitious public works projects aimed at modernizing the nation's infrastructures. As universities, stadiums, housing projects, highways, and airports, for example, were commissioned, a fresh set of visual images appeared on the urban landscape and the government's ideological stance of presenting itself as the restorer of lost moral values acquired a specific physical form.

Many of the cultural artifacts that were produced in the thirties and forties can still be viewed today. They range from the decorative motifs that adorn the interiors and exteriors of many public buildings to the organization of whole neighborhoods that were constructed during this period; from the statues that grace public parks and gardens to the historical monuments (castles, palaces, churches) that were carefully restored by the State. In each case, these works can be approached and interrogated as objects of visual and material culture the primary goal of which was to set up and maintain a picture of the world that was both constitutive and affirmative of hegemonic cultural and historical values.

Executed under the auspices of the Secretariado de Propaganda Nacional, headed by António Ferro, and by Duarte Pacheco's Ministério das Obras Públicas e das Comunicações, these works brought major changes to the face of both the nation's cities and provincial towns. ${ }^{2}$ Moreover, given both men's modernist sensibilities, these projects often resulted in works of great aesthetic interest that were decorated by some of Portugal's leading visual artists. While the study of the political and social climate that contributed to the conception 
and completion of these projects constitutes an important area in the understanding of Estado Novo history, it is not my intention in this essay to document the technical and aesthetic contributions of Ferro, Duarte Pacheco, or other individual artists or architects whose work exemplifies a particular "spirit of the age." culture developed by Nicholas Mirzoeff, I hope to show instead how, long after their inception, certain artifacts of Salazarist visual culture continue to play an important role in the Portuguese national imagination.

Visual culture is concerned, above all, with events in which a consumer seeking information, meaning, or pleasure contemplates or interacts with objects or technologies designed either to be looked at or to enhance natural vision (Mirzoeff Intro. 3). It is often associated with our present age, a time in which visual imagery of all kinds (video, the Internet, virtual reality, etc.) has come to take precedence over the written word, disrupting and challenging attempts to define culture in purely linguistic terms (Mirzoeff Intro. 7). While practices that make use of spectatorship (the look, the gaze, the glance, the practices of observation, surveillance, and visual pleasure $)^{4}$ have certainly reached post-modern levels of sophistication and complexity that were unthinkable for previous generations, the roots of modern visual culture reach back at least to the mid-nineteenth century. ${ }^{5}$

In his Introduction to Visual Culture, Mirzoeff identifies the "Age of Photography" (1839-1982) as initiating a period in Western culture in which a "dialectical logic" of the image predominated. ${ }^{6}$ With the advent of photography, a relationship was set between the "viewer in the present and a past moment of space or time that [the photograph] represents" (Mirzoeff Intro. 8), thereby changing the very nature of human perception. The ability to capture the past led to the creation of what Walter Benjamin has called the "optical unconscious," and experience began to be understood as an image (Mirzoeff Intro. 71). In Portugal, the visual gained unprecedented importance during the 1930s and 1940s as a site around which the state sought to construct its discourses of power. For a culture in which literacy was highly uneven, the visual represented a means of reaching new audiences, and use was made of its powers of "sensual immediacy" (Mirzoeff Reader 9) to communicate both directly and indirectly with these audiences.

By examining four well-known visual sites found in present day Lisbon according to a methodology that "takes account of the importance of image making, the formal components of a given image, and the crucial completion of that work by its cultural reception" (Mirzoeff Intro. 3), I will identify the original context in which these sites were conceived, and then go on to show how differing circumstances have conditioned the cultural reception of these images in the years that have since passed. While the initial "message" of the artifacts was essentially the same, the original ideological contents of each project have suffered different fates as viewers from subsequent generations have alternately forgotten or reinterpreted the "stories" that were being told. More specifically, in two cases these visual artifacts have achieved an iconic status that would seem to go well beyond their creators' original intentions. In my "reading" of these particular images, I will attempt to account for their continuing appeal in post-Salazarist Portugal by posing the question of their ability to invoke or include images that run counter to the representative codes that their creators employed. By thus highlighting the moments in which these images have stood as challenging places of social interaction and definition within which the structures of both local and national experience were shaped, contested, debated, and transformed (Mirzoeff Reader 6), I hope to contribute to the development of a history of visual culture in Portugal.

While the political and ideological contents of my first examples have in fact all but faded from present memory, an attempt to "recuperate" their projected original impact will serve as a point of departure for understanding the visual discourses employed by the State during the period in question. Most residents and visitors to Lisbon are no longer aware of 
this, but extensive renovations of the exteriors of both the Castelo de São Jorge and the Sé Patriarcal took place during the late 1930s. These renovations must have had the almost immediate effect of altering the relation of the capital's citizens to the well-known historic structures. Neglected by earlier generations and allowed to fall into disrepair, neither the Sé nor the Castle previously would have stood out greatly from its surrounding buildings. However, the cleaning, repair, and "sharpening" or "correction" of their facades, in conjunction with an urban renewal project that led to the destruction of many of the historic buildings in the nearby Mouraria quarter, highlighted them within the modern urban landscape. ${ }^{7}$ This renovation, in turn, granted the buildings an air akin to that of a simulacrum, that is, as both a representation and a trace of the lost contours of medieval Lisbon. Dominating the downtown skyline, these restored structures came to stand as concrete physical proof of Salazar's commitment to restoring the values of a national past as part of his program of spearheading a ressurgimento nacional. More specifically, their intertwining references to state and church power hearkened back to a pre-Republican, preliberal moment in national history and implicitly championed the Estado Novo as a force that would protect and assure the continuation of a morally conservative social code.

A similar case of urban development during this period that also entailed imposing a constructed and contrived historicism on Lisbon's urban fabric can be found in the example of the Praça do Areeiro designed by the architect Luís Cristino da Silva (1938-49). Here was planned a whole new neighborhood around what amounts to a series of architectural quotations drawn from previous eras (fig. 1). This grouping of residential buildings around an escudo-shaped central plaza is representative of Duarte Pacheco's turn away from modernist-inspired structures in favor of an aesthetic of historical monumentality. In this instance, oblique allusions to tastes reminiscent of the Mannerist and the Pombaline periods also serve to underscore important alliances within Salazar's government. The historicist content of this urban project refers back to both the period of imperial grandeur and to a moment in which there emerged an alliance of capital and State that would subsequently sustain and develop the imperial project. It is therefore fitting that a commemorative statue depicting heroic soldiers and colonizers was originally planned to occupy the praça's center (França, Urbanismo 96).

Lisbon, like any city, is of course a living space and its inhabitants do not always respond to, interpret or utilize its buildings and squares in the fashion that urban planners would expect or desire. Also, governments, secretariats, and local bureaucrats rarely last as long on the political scene as edifices live on within the urban matrix. While I have been discussing the Castelo, the Sé, and the Praça do Areeiro as visual "texts," emphasizing their "preferred" readings which reflect back upon the dominant cultural order (Hall, cited in Turner 85), most residents and visitors to today's Lisbon are surely unaware of the context within which these projects were originally conceived. They may be ill-prepared, therefore, to engage in the conceptual associations and extra-visual leaps that enable these preferred readings to succeed. ${ }^{8}$ Not all artifacts maintain their status as "visual stories" that are capable of interpellating the viewer, and certain buildings, like the Sé and the Castle, are no longer looked at within the ideological frames of Estado Novo aesthetics. A change in cultural context often, however, affords the visual text a wider set of meanings which can, in turn, include both negotiated and oppositional strategies for decoding its message (see Hall/Turner 86). ${ }^{9}$

In the interplay of text and historical change, a new space is opened up for the viewer to respond to and reinterpret the preferred or dominant reading of these artifacts. Borrowing from John Fiske's notion of counterknowledge, a mode of oppositional knowledge that recovers that which has been repressed by dominant discourses, ${ }^{10}$ I will characterize these points or moments of revision as counter-images. Diverging from the more traditional, 
straightforward practice of seeking contestatory images in works produced by such groups as the Neo-Realists or the Surrealists, my use of the concept of counter-image is centered on the premise that all works contain within themselves the possibility of being reread or recontextualized in a way that may challenge the ideology according to which they were produced. While it is true that both the Neo-Realists and the Surrealists began to exhibit at this historical juncture and that they identified themselves in opposition to the regime, the artistic styles they developed questioned the official aesthetics of the day through the employment of different sets of representational codes. A counter-image, on the other hand, is to be found in relation to or within a given work, acting as a supplement to or negation of that work's preferred reading or interpretation. Whether produced in accordance with the officially sanctioned aesthetics, in opposition to it or according to some intermediate, negotiated position, any artifact is capable of producing its own counter-image. ${ }^{11}$ As Fiske reminds us, "counterknowledge can never be repressed entirely" (quoted in Mirzoeff Reader 127). Likewise, the viewer or reader who moves to uncover the possible counter-images contained in a visual or material artifact must engage in a rearticulation of facts, events, and bits of knowledge that the dominant order has repressed or dismissed as insignificant (Fiske 191).

According to this definition of counter-image, one may therefore affirm that even the most propagandistic of works may afford an opportunity for the viewer to elicit his or her own counter-image while apprehending the work in question. Such is the case of the Padrão ${ }^{12}$ dos Descobrimentos which is, without doubt, one of the most recognizable and enduring memory sites constructed by the Salazar regime. Designed originally for the 1940 Exposição do Mundo Português, ${ }^{13}$ this monument was rendered permanently in stone in 1960 to commemorate the quincentenary of the death of Prince Henry the Navigator. At first glance, the Padrão (fig. 2) seems to allow for a relatively low quotient of cultural ambivalence. Its cultural contents include a wide range of patriotic symbols: an enormous image of the sword of Avis placed within the form of an even larger cross, reproductions of the flag of D. João I, and two parallel lines of sixteen figures ascending the stylized prow of a ship, each bearing some identifying allegorical mark (sword, padrão, astrolabe, rosary, cross, or book). Given the angle from which the figures are observed, their already largerthan-life proportions are greatly magnified as the viewer cranes his or her neck to look up, while the monument's implicit dynamics of motion force attention to move upward toward the figure of the Infante (fig. 3). This, in effect, reinforces Prince Henry's centrality in both the actual structure of the monument and in the specific view of Portuguese national history that is being presented. Eliciting a series of cultural-historical memories that are presented as straightforward and unambiguous, the sculpture inspires impressions of wonder and admiration while it invites the viewer to revisit Portugal's moments of grandeur and to celebrate the courageous deeds performed in the name God and pátria.

While the Padrão's overstated realist depiction of the larger-than-life heroes of the Age of Discoveries may today be considered by many as little more than an aesthetic anachronism, it continues to occupy a prominent place in Lisbon's urban geography. Since the fall of the Estado Novo, however, its main representational thrust will necessarily point toward a more ambiguous cultural message than the one that was originally intended. Such is the case of a photograph taken in 1975 (fig. 4), in which the Padrão's monumentality is visibly diminished by the presence of the enormous shipping crates that occupy the foreground. Containing the belongings of the retornados forced to undertake a rapid retreat from Portugal's African colonies following their independence, the crates symbolically mark the end of a five-hundred-year cycle of Portuguese colonial overseas expansion. Here, I would argue that the Padrão's presence within the photographic composition figures as an ironic allusion to the ultimate failure of Salazarist discourses to determine the future of 
Portugal's colonial possessions. While the Acto Colonial of 1930 may have affirmed that it was nation's "historical mission to possess and colonize overseas territories" (Oliveira Marques 679), this picture attests to exactly the opposite-that nationalist discourses, like nationalist works of art, can always be subject to interpretation, amendment, and outright rejection.

It should be noted, nonetheless, that in this specific instance the Padrão has actually become an element in a more complex composition. Inserted into a new context and manipulated for a purpose that is quite different from the original, the Padrão's status as an unalterable "text," literally written in stone, has been ultimately compromised. Indeed, the fact that the Padrão dos Descobrimentos can still be visited, viewed, and photographed opens up the possibility of studying it as a continuing visual event. As such, it may be analyzed in terms of its status as text and in light of its context; likewise, it may be approached from the point of view of either the producer or the consumer. Curiously, this monument's dogmatic formalism and its producers' goal of communicating a relatively unambiguous cultural message seem almost to beg that its "readers" move to appropriate its message through acts of photographic recontextualization.

A more recent example of this recontextualization of the Padrão dos Descobrimentos can be found on the cover of a book on U.S.-Portuguese relations during the $1973 \mathrm{Arab}-$ Israeli Yom Kippur War (fig. 5). ${ }^{14}$ In the particular photo that is used, Henry Kissinger, accompanied by Rui Patrício, Marcelo Caetano's Minister of Foreign Affairs, appears in the foreground, directly below the figure of Prince Henry the Navigator. Clearly, several possible meanings can be derived from this ironic pairing, the first and most logical based on the historical circumstances behind Kissinger's 1973 visit to Lisbon. As the book's contents explain, Portugal had no choice but to let the U.S. establish an airlift to Israel via the Lajes air base in the Azores in October and November 1973. Nevertheless, in return for that concession, Portugal was able to convince Washington to soften its language in key congressional legislation regarding the prohibition of the sale of arms to Portugal for use in the colonial wars being waged in Africa. In the historical context of Kissinger's visit, therefore, his appearance under a statue that was quintessentially symbolic of Salazarist ideology could be read as an implicit affirmation on the part of the U.S. to continue its support for a regime that was considered a vital ally in the Cold War.

From our historical standpoint, on the other hand, the grouping of figures in this photograph seems hauntingly ironic. First and foremost, we know what these men apparently do not at the time of the photo - that the Salazar-Caetano regime was to survive for only four more months. It could also be argued that this photo implicitly proposes that, by the 1970 s, the U.S. Secretary of State had supplanted the late medieval prince as ruler of the seas and patron of global expeditions. Like the melancholic moment associated with the reduction of Portuguese national geographic space captured in the 1975 photo, this image makes use of the Padrão dos Descobrimentos's representational value as a symbol of fairly unproblematic, straightforward patriotic pride in order to evoke the ambiguities of a specific historical time. $\mathrm{Be}$ it 1973 or 1975 , the tensions connoted in each image are closely associated with the imminent decline of Salazarism and of an ideology that used history as a defense for Portugal's continued colonial presence in Africa.

A final photographic image of the Padrão that I wish to discuss does just the opposite, that is, it seeks to erase the monument's obvious connection to Salazarist aesthetics and ideology. Illustrating the slogan "The Thrill of Discovery. Portugal," the Padrão appears in the foreground of a 1994 advertisement distributed in the English-language press by the Portuguese National Tourist Office (fig. 6). ${ }^{15}$ Behind it is the Tower of Belém, another wellknown landmark associated with the Age of Discovery. Photographed at sunset, the sculptural and architectural details of both structures are impossible to ascertain, but the 
silhouette figure of Prince Henry, occupying the exact center of the photo immediately draws the viewer's attention. He is then identified in the accompanying text which informs us that this "600 year old Portuguese," Henry the Navigator, and men like him, should take credit for Portugal's role in linking such distant cultures as Japan, the U.S., Brazil and India. When making note of a Portuguese presence in Africa, however, the advertisement speaks only of "South Africa, where a monument was raised to commemorate the rounding of the Cape of Good Hope." Thus, while factually correct, this text does a very good job of suppressing all memory of Portugal's twentieth-century colonial experience in Angola, Mozambique, Guinea-Bissau, São Tomé and Príncipe and Cape Verde. Like the image that is used to draw the viewer's attention, the details of recent Portuguese history have also been blurred in this attempt to market the nation's past as an early example of multi-cultural exchange. Ironically, however, the ephemera referred to in this ad is strikingly similar to that which motivated the statue's construction in the first place-while Henry the Navigator died in 1460 , five hundred years before the construction of the monument, he was born in 1394, exactly six hundred years before the creation of this particular publicity campaign. ${ }^{16}$

As this final example attests, the Padrão dos Descobrimentos can only be distanced so far from the preferred reading that its creators envisioned for it. Even when an image of the monument is reproduced, reappropriated, or put to the service of a counter-discourse that seeks to suppress the political and aesthetic codes of the recent past, Salazarist discourses of national identity seem always to lurk just under the surface. I would argue that this occurs because the Padrão's hyper-realist aesthetic works to smooth over contradiction by positing the viewer as a unified and knowing subject (Belsey 90). As theorists of cultural studies remind us, cultures are continually seeking to create a working equilibrium by striving to reconcile the tensions caused by a variety of contradictory factors. Classic realism aims to overcome these tensions by employing a declarative mode of address that "[imparts] 'knowledge' to a reader whose position is thereby stabilized through a privileged discourse which is to varying degrees invisible" (Belsey 91). The unequivocal picture of Portuguese national history that the Padrão communicates provides a limited number of viewing positions from which the spectator may decode its message. For this reason, counter-images or strategies of resistance to the statue's ideological effects can only occur after the original has been reframed by the photographic lens or by some other vehicle of interpretation.

Outside the realm of propaganda, it is rare, however, to encounter a visual or written text that so clearly and consistently interpellates its viewers, inserting them into a particular relationship to the story that is being told and, by extension, into an uncomplicated relationship to dominant ideologies (Turner 99). In most instances, attempts to reconcile the tensions within a given culture lead to the production of cultural artifacts that are to some degree ambivalent, and that never merely celebrate or reinforce a univalent set of culturally located values (Fiske and Hartley, quoted in Turner 97). It is this type of image, moreover, that is more likely to present the possibility of locating strategies of resistance within its own representational boundaries. As Graeme Turner notes, in these cases the potential for resistant readings becomes a property of the texts themselves, for networks of ambiguity and contradiction "invite and accommodate the reader's adoption of different, even ideologically contradictory subject positions." (109). In keeping with Turner's emphasis on a text's potential polysemy, the final example of Salazarist visual culture that I wish to discuss is a more openly ambiguous work of public art. The set of eight murals that Modernist painter José de Almada Negreiros designed for Lisbon's Alcântara Maritime Station will be approached as a visual text that contains several points of divergence in relation to the very representational codes that the artist is employing.

Executed between 1943 And 1945, these murals adhere to a series of naturalistic and allegorical standards that assured the paintings' immediate public success. The first of the 
two single panels that occupy either end of the rectangular room consists of a rustic scene entitled "Ó Terra Onde Eu Nasci" and includes such stereotypical images as a village church, a picnic scene, an old woman selling cakes, and a courtship carried out between a sailor and a young woman (fig. 7). The second single panel bears the legend "Dom Fuas Roupinho 1.0 Almirante da Esquadra do Tejo," depicting this Admiral who was saved from the Devil through the intervention of the Virgin while stag hunting on a foggy day at the sitio (upper city) of Nazaré (fig. 8). Continuing this tendency to utilize myths or legends well known by the common Portuguese citizen, a triptych of murals that adorns the western wall narrates the story of the "Nau Catarineta," in which the sailors, lost at sea and suffering from great hunger, receive an angel, who successfully conquers the devil and leads them to shore (fig. 9).

While these panels' use of traditional stories and images was interpreted at the time as indicative of the artist's having softened the vanguard techniques that had scandalized and frightened the citizens of Lisbon during the 1910s and 1920s (Anos 40110 ), several more recent assessments have called attention to the fact that they do diverge somewhat from contemporary "official views" regarding the Portuguese character. For Artur Portela, the Portugal alluded to in these murals was vastly different from those images cultivated by the Estado Novo: "é um outro Portugal, profundo, mágico, encantatório, de um imaginário popular, vivo, em contraste com o imaginário historicamente erudito, guerreiro, imperialista" (Portela 94-95). In these panels, Almada may, in fact, have been commenting on the State's misplaced emphasis on history and on the Age of Discoveries in particular. ${ }^{17}$ It also seems true, however, that the artist was, to a great extent, reproducing or re-encoding the dominant ideological discourses regarding the povo and its idealized role within a supposedly "pure" rural or maritime culture.

Because these murals are clearly conventional in their content and their form, I find it all the more intriguing that some incongruous and surprising images begin to appear upon closer inspection of their background. In the small and easily overlooked details of the most "traditional" panels, the artist included several ironic references both to himself and to his present-day perspective on the myths represented. Besides inserting his own self-portrait in a depiction of the devil that appears in the first panel of the "Nau Catarineta" triptych, the final panel of this series showing the crowd that greets the sailors also contains a bourgeois, decidedly urban couple who watch the others from the lower left corner of the composition. Exactly opposite this pair who observe the sailors and the townspeople celebrating the reunion between the captain and his daughters, in the upper right-hand part of the crowd, we then find the image of a coach that has transported three other outside guests who, by their dress and demeanor, seem to represent three journalists who have also arrived from the city to report on the event (Gonçalves 207). This technique of incorporating anachronisms and other references to the murals' production undermines the panels' realist illusion and draws attention to their status as representations or texts. The spectator is distanced, at least from time to time, from the fictional world of popular myth (Belsey 92), as the artist strives to achieve some degree of internal detachment from that ideology by invoking ironic subject positions within the fictions that are displayed.

The tendency to diverge from a mythic view of national experience and thus allow for the intrusion of references to contemporary experience is carried over and amplified in the triptych that adorns the eastern wall of the Gare Marítima de Alcântara. These panels consist of three stylized scenes depicting daily riverfront life in Lisbon (fig. 10). In the foreground of these panels, we see three women loading coal onto a ship, the prow of two fishing boats, one of which reads 'Tejo' and the other most likely 'Almada, ${ }^{, 18}$ and a view of three varinas, typical Lisbon fishwives, who are inspecting their wares. As a contrast to the human activity represented in the foreground of these scenes, the city that appears behind these figures is 
entirely devoid of life, with the exception of a trolley car that passes by the Sé, elegantly described by José Augusto França as "um fantasma silencioso a viver dentro do vazio mortal que lhe assiste (Almada 370)." These ghostly images of a familiar cityscape-the aqueduct, the Óbidos palace, and, not surprisingly, the Castle and the Cathedral-seem to present a view of the nation's capital as inhabited by a silently waiting population. It is left to the viewer to decide what is expected or hoped for but, given the dates during which these murals were conceived and executed, it does not seem improbable to venture that the city is waiting, perhaps, for the end of the Second World War and a much desired return to democratic institutions.

These murals, of course, were specifically designed as visual decorations for a waiting room, that is, for a space in which the spectator's main purpose was not that of formally examining or appreciating visual art. Within this space, the act of viewing was to be both a collective and an informal experience. In this sense, these murals, like the Castle, the Sé or the Praça do Areeiro, present another example of the everyday experience of the visual (Mirzoeff, Introduction 7). As was the case with the other examples of Salazarist visual culture that I have studied, responses to these murals will have changed over time and according to the cultural baggage that each spectator brings to them. Today, in fact, they are rarely seen in their original context. While the Maritime Station is still in use as a docking point for visiting international cruise ships, passengers embark and disembark on the floor below. The room housing the murals, on the other hand, is now formally called the "Salão Almada Negreiros," and it is used to house temporary, often specialized, commercial exhibits. ${ }^{19}$ In earlier decades, however, the Station witnessed much heavier traffic with a higher proportion of Portuguese nationals regularly moving through this space.

By the 1960s and early 70s, many of the soldiers departing for the colonial wars left from this station; also in the 1970s a large number of retornados most likely passed through. More recently, in the summer of 1998, the Gare Marítima de Alcântara received the ship Vasco da Gama, and the refugees that it was transporting to Lisbon who were fleeing the armed conflict in Guinea-Bissau spent many hours waiting below these images. In each of these instances, viewers' responses to the murals must have been quite different. Putting aside the images contained in a panel such as "Ó Terra Onde Eu Nasci," the very resonance of its title will change according to whether one is leaving or entering the national space. Of course, the question of whether or not he or she actually was born in metropolitan Portugal is also as important as the passengers' reasons for embarking or disembarking. ${ }^{20}$

These divergent possibilities indicate, of course, that the "text" of Almada's murals, while already constituting a somewhat negotiated position in regard to official Estado Novo aesthetics, continues to be subject to differing and successive "readings." As Graeme Turner reminds us, texts are "loaded with an excess of meaning, leaking through the boundaries of any 'preferred' readings, into the social formations of the readers, and thus producing a range of meanings and pleasures" (109). Given the generally conventional nature of the images contained in these panels, it is logical that certain viewers see in them a reflection of the Estado Novo's promotion of rural values and references to the period of Portugal's maritime grandeur. For those who focus more on the anomalous details of the paintings, however, they could just as easily be understood as attempting a subtly ironic reworking of such narratives of Portuguese identity. Furthermore, whatever position these readings may support will probably also depend on where, as well as when, they take place. At the present time, in fact, they are more likely to occur in response to reproductions, rather than through a viewing of the murals in their original setting.

As was previously noted, with a few important exceptions, it is now virtually impossible to view Almada's murals within their original context. At the same time, nevertheless, as the distance (both temporal and spatial) that separates them from this context grows, these well- 
known images have begun to circulate in new, sometimes unexpected, ways. Nicolas Mirzoeff, citing events such as the blockbuster art exhibition and the reproduction of a painting on a book jacket or in an advertisement, reminds us that our contemporary culture is very much structured by a variety of visual experiences, most of which take place aside from more formally structured moments of viewing. (Introduction 7). Almada Negreiros' work, not surprisingly, has been presented to the Portuguese public in all these forms since the 1980 s. $^{21}$ Once the artist's images were embraced by a post-revolutionary visual economy characterized by postmodern norms of mass culture consumption, new opportunities for assessing their hold on the collective imagination have arisen.

As was the case with the Padrão dos Descobrimentos, several of Almada's paintings have been used as cover art for books that do not ostensibly propose an aesthetic analysis of the artist's works. The best example of this can be found in the images taken from the Alcântara murals that decorated the covers of a series of linguistic texts subsidized in the 1980 s by the Portuguese Ministry of Education. These books were designed for primarily foreign distribution and their covers may be seen as serving as a sort of calling card for contemporary Portuguese culture abroad. Tellingly, however, only certain elements of Almada's Alcântara murals were chosen for this purpose, such as the central panel of the series "Quem Não Viu Lisboa Não Viu Coisa Boa" which graces the cover of Vasco da Fonseca's Dictionnaire des verbes irréguliers et des conjugaisons difficiles da la lengue portugaise. When displayed in this new format it is all but impossible for the viewer to develop a reading of this panel either in relation to the two that originally flanked it, or based a knowledge of Salazarist cultural politics. Thus many of the ironic touches referred to in my specific reading are almost lost and the cover image is easily approached as comprising an exportable visual marker of portugalidade.

In another cultural sphere, that of the large-scale, specialized art exhibition, a somewhat similar process of deterritorialization has occurred. Over the past two decades several important exhibits on Almada's literary and artistic production took place in both Lisbon and Madrid. ${ }^{22}$ These exhibitions and the documentation assembled around them undoubtedly have allowed for a better understanding of the artist and his processes of production. Reproductions of Alcântara Station murals (and also of a complementary set that the artist subsequently painted in the Gare Marítima da Rocha do Conde de Óbidos) figured prominently in these exhibits and, in several instances, they were accompanied by sketches done by the artist as preliminary studies. As they reveal the different compositional stages involved in reaching the final images, several of these sketches seem to confirm my readings of the final contents of the panels entitled "Ó Terra Onde Eu Nasci" and "Quem Não Viu Lisboa Não Viu Coisa Boa."23 Interestingly, the preliminary images for the former are strikingly similar in both content and composition to a series of propaganda posters produced during the 1930 s. In comparison to these earlier studies, the magical qualities apparent in Almada's final version take on a more markedly subversive bent. ${ }^{24}$ In the latter case, the studies done for the series entitled "Quem Não Viu Lisboa... " reveal a progressive elimination of human figures from the scene, the fact of which lends weight to the symbolic importance of the silently waiting city depicted in the final version of the panel.

Even though their "rediscovery" as artistic objects worthy of public display has led to a better understanding of the processes behind the conception and execution and of these murals, there are clearly some drawbacks associated with this same interest in disseminating Almada's work. One is that it has lost a large portion of the visual impact that was derived from viewing the work in its original context. Once the images of the murals were included in these large-scale exhibits, freed from the walls they were designed to decorate, they no longer reflect back on the activities associated with the public space for which they were 
designed. As an important consequence of this move, they have also lost much of their capacity to act as artistic documents of a specific historical period.

It is inevitable that the ongoing process of canonization of Almada's work, accompanied by its increasing commercialization, allows new interpretations of the murals' contents to come to the fore. However, unlike the counter-images that I identified within the boundaries of the murals, these new associations will not necessarily be read as standing in response to specific Salazarist discourses on Portuguese identity. On the contrary, their inclusion in other media demonstrates that the conceptual frames of Estado Novo aesthetics have definitively shifted. Today, these images no longer interpellate the viewer, asking that he or she accept or reject the quite specific picture of the Portuguese national experience defended by the Salazar regime's ideological discourses. Whether they are used to promote an image of the nation for export or are seen as a valued part of the cultural patrimony, Almada's murals, like the Padrão dos Descobrimentos, have now taken on a new significance as a visual event that often has little or nothing to do with their original preferred reading.

That both the Padrão dos Descobrimentos and Almada's murals continue to appear regularly as key elements in the national visual economy speaks to the legacy of Salazarist cultural practices in present-day Portugal. These artifacts now, however, clearly have a great deal to say about new ways in which the visual is being employed in contemporary Portuguese society. As the Padrão's cultural contents are closely allied with a specific historical view of national experience, new, reframed images of it have repeatedly been put to the service of revisionist views of past experience. Almada's murals, in contrast, were originally conceived as a politically ambivalent visual text. This more open quality of Almada's work has allowed for the Alcântara murals to be repackaged and recycled as commodities within a new visual culture, characteristic of post-revolutionary Portugal, that has all but forgotten their contextual historical significance.

\section{NOTES}

${ }^{1}$ In her richly illustrated volume Exposições do Estado Novo 1934-1940, Margarida Acciaiuoli carefully documents the preparation, execution, and reception of these and other projects, commenting on the political activity surrounding them and analyzing their actual physical arrangement.

${ }^{2}$ While Ferro served as editor of the Modernist review Orpheu (1914), his enthusiasm for the Modernist and Futurist aesthetic can best be found in his publications of the early twenties: A Idade do Jazz-Band (1923) and Gabriele d'Annunzio e Eu (1922). In 1927, he published Viagem à Volta das Ditaduras in which he enthusiastically described the dictatorships of Mussolini, Primo de Rivera and Mustafá Kamel. He was named Director of the SPN (later rebaptized the Secretariado Nacional da Informação in 1945) in 1932, after publishing a series of interviews entitled Salazar O Homem e a Sua Obra. Ferro would remain as the head of the SPN/SNI until 1950, when he was named ambassador to Switzerland. Duarte Pacheco was trained as an engineer. After working as the director of Lisbon's Instituto Superior Técnico, he was named Minister of Obras Públicas e Comunicações, and also served simultaneously as president of Lisbon's Câmara Municipal. He was killed in an auto accident in 1943.

${ }^{3}$ For a detailed historical account of the many projects sponsored by the SPN/SNI, see Jorge Ramos do Ó, Os Anos de Ferro: $O$ dispositivo cultural durante a "Politica do Espirito" 1939-1949. 
${ }^{4}$ I am borrowing here from W.J.T. Mitchell's Picture Theory, as cited in Mirzoeff, Introduction 7.

5 "The hyper-stimulus of modern visual culture from the nineteenth century to the present day has been dedicated to trying to saturate the visual field, a process that continually fails as we learn to see and connect ever faster" (Mirzoeff, Introduction 5).

${ }^{6}$ Mirzoeff identifies the present age as one in which the paradoxical or virtual image is the norm (Introduction 8).

${ }^{7}$ See Marina Tavares Dias, Lisboa nos Anos 40 Longe da Guerra, pp. 14-21, for a series of images that capture the striking changes brought about by this project.

${ }^{8}$ In my use of "visual leap" and in several of the observations that follow, I am borrowing from Ann Reynolds' essay on educational exhibitions at the American Museum of National History entitled "Visual Stories" (The Visual Culture Reader 133-147).

${ }^{9}$ In the case of the Praça do Areeiro, it is ironic to note that this neighborhood, which was originally conceived as symbolic of Lisbon's position as "Capital of the Empire" (França, Urbanismo 96), was almost renamed Praça General Humberto Delgado immediately after the 1974 revolution. Today, of course, it bears the name of Francisco de Sá-Carneiro and is graced with a monument commemorating the tragic 1980 death of the Social Democrat Prime Minister. Rather than indicating that the original "meaning" of the representational codes were lost, these name changes may actually register a knowledge of the Areeiro's original aesthetics and ideological pact. In the first case, a move to identify the square with a hero of the resistance would seem to result from an oppositional decoding of the original message. The final decision to rename it in memory of Sá-Carneiro, on the other hand, reveals a more negotiated decoding.

${ }^{10}$ Fiske develops his theory of counterknowledge most clearly in an essay entitled "Blackstream Knowledge: Genocide" that examines the manner in which counterknowledge circulates in Black media. While his specific examples deal with the ways in which discourses on AIDS are deconstructed and rewritten by political analysts associated with Black Liberation Radio, many of his observations regarding oppositional knowledge can be applied to wider spectrum of cases.

${ }^{11}$ Works created by the Surrealists and Neo-Realists can be studied, of course, as also containing their own counter-images.

${ }^{12}$ While the term padrão literally means a standard or a fixed pattern, it is also used to refer to stone monuments set up by the Portuguese in their newly discovered lands during the fifteenth and sixteenth centuries.

${ }^{13}$ Designed by architect Cotinelli Telmo, the Padrão was executed by sculptor Leopoldo de Almeida.

${ }^{14}$ José Freire Antunes, Portugal na guerra do petróleo: Os Açores e as vitórias de Israel. Carnaxide: Edline, 2000.

${ }^{15}$ I wish to thank Pat Odber de Baubetta for bringing this advertisement to my attention.

${ }^{16}$ The exact text reads: "Many old folk have stories to tell. Like this 600 year old Portuguese. You're looking at Henry the Navigator. But don't be fooled by appearances. This year is the young Prince's $600^{\text {th }}$ birthday."

${ }^{17}$ As Almada explained in an interview, the myth of the "Nau Catarineta," in contrast with the "História Trágico-Marítima" or the "Fundação de Lisboa por Ulisses," represented, in his view, "the only real source in the oral tradition regarding the Portuguese people and the sea" (França, História 370).

${ }^{18}$ This would appear to be a reference to the city on the southern bank of the river and to the artist himself.

${ }^{19}$ On a recent visit to the Station, in February 2001, a trade fair for various commercial pharmaceutical distributors was being held. 
${ }^{20}$ For the record, the artist Almada Negreiros was not born in metropolitan Portugal. He was born on April 7, 1893 in the colonial territory of São Tomé and Príncipe.

${ }^{21}$ To my knowledge, the murals in question have yet to appear in print advertising, but Almada's famous portrait of the poet Fernando Pessoa was used in a billboard campaign for Delta Coffee. Inserting the brand's logo on the cup from which the poet drinks, the slogan found under the reproduced image read: "Todas as pessoas bebem café Delta."

${ }^{22}$ Besides the Exposition Os Anos 40 na Arte Portuguesa held at the Fundação Calouste Gulbenkian from March 30 to May 9, 1982, Almada was the subject of retrospectives in 1983-84 (Fundación Juan March, Madrid), 1984 (Gulbenkian), and 1993 (at the Centro Cultural de Belém and the Biblioteca Nacional de Lisboa). While the notion of the blockbuster exhibit is difficult to translate to a nation comprised of just ten million inhabitants where, until very recently, patterns of material and cultural consumption lag noticeably behind those of Western Europe and the United States, I believe it safe to characterize at least the Centro Cultural de Belém exhibit as such.

${ }^{23}$ These sketches can be viewed in the catalogues from the Gulbenkian and the Centro Cultural de Belém exhibits.

${ }^{24}$ For information on the production and circulation of such propaganda posters, see Cartazes de Propaganda Politica do Estado Novo, the catalogue of an exhibit held at Lisbon's National Library in 1988. More specifically, in the final version, images of workers threshing wheat and the interior view of the home (a typical image for propaganda posters that allude to harmonious domestic spaces) are removed. Among the new figures added are the lovers and the old woman selling cakes.

\section{WORKS CITED}

Acciaiuoli, Margarida. Exposições do Estado Novo 1934-1940. Lisboa: Horizonte, 1998.

Almada. Catalogue of an art exhibit at the Fundação Calouste Gulbenkian. July 20-October 14, 1984. Lisboa: Fundação Calouste Gulbenkian, 1984.

Almada A Cena do Corpo. Catalogue of an art exhibit at the Centro Cultural de Belém. October 27, 1993-January 15, 1994. Lisboa: Fundação das Descobertas / Centro Cultural de Belém, 1993.

Os Anos 40 na Arte Portuguesa. Catalogue of an art exhibit at the Fundação Calouste Gulbenkian. March 30-May 9, 1982. Lisboa: Fundação Calouste Gulbenkian, 1982.

Antunes, José Freire. Portugal na guerra do petróleo: Os Açores e as vitórias de Israel. Carnaxide: Edline, 2000

Belsey, Catherine. Critical Practice. London and New York: Methuen, 1980.

Cartazes de Propaganda Politica do Estado Novo 1933-1949. Catalogue of an exhibit at the Biblioteca Nacional. Lisboa: Biblioteca Nacional, 1988.

Cunha, Alfredo. Naquele Tempo. Lisboa: Contexto, 1995.

Dias, Marina Tavares. Lisboa nos Anos 40. Lisboa: Quimera, 1997.

Fiske, John. "Blackstream Knowledge: Genocide." Media Matters. Minneapolis: Minnesota UP, 1996, 191-216.

França, José-Augusto. A Arte em Portugal no Século XX. 3rd ed. Lisboa: Bertrand, 1991.

- Amadeo e Almada. Lisboa: Bertrand, 1983.

. Lisboa: Urbanismo e Arquitectura. Lisboa: Horizonte, 1997.

Gonçalves, Rui Mário. “Os Murais dos Anos 40.” Almada. Lisboa: Fundação Calouste Gulbenkian, 1985. 196-210.

Marques, A. H. de Oliveira. Breve História de Portugal. Lisboa: Presença, 1996. 
Mirzoeff, Nicholas. An Introduction to Visual Culture. London: Routledge, 1999.

Mirzoeff, Nicholas, ed. The Visual Culture Reader. London: Routledge, 1998.

Ó, Jorge Ramos do. Os Anos de Ferro. O dispositivo cultural durante a "Política do Espirito" 1933-1949. Lisboa: Estampa. 1999.

Portela. Artur. Salazarismo e Artes Plásticas. 2nd ed. Lisboa: ICALP, 1987.

Reynolds, Ann. "Visual Stories." The Visual Culture Reader. Ed. Nicholas Mirzoeff,. London: Routledge, 1998, 133-147.

Turner, Graeme. British Cultural Studies: An Introduction. $2^{\text {nd }}$ ed. London: Routledge, 1996 
ILLUSTRATIONS
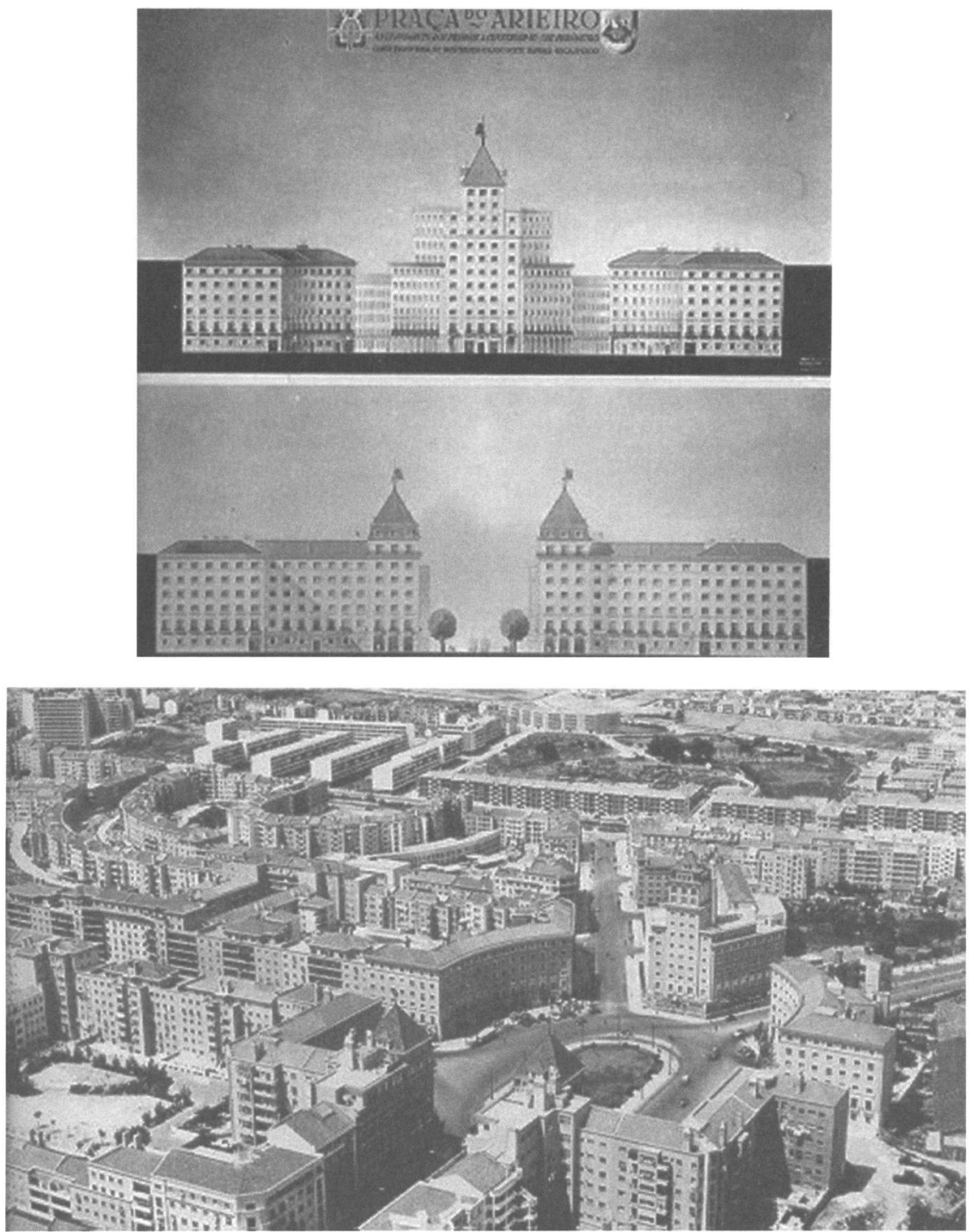

Fig. 1 The Arquitect's design for the Areeiro and an aerial view of the completed project from Os Anos 40 na Arte Portuguesa (Lisboa: Fundação Calouste Gulbenkian, 1982) 135. 


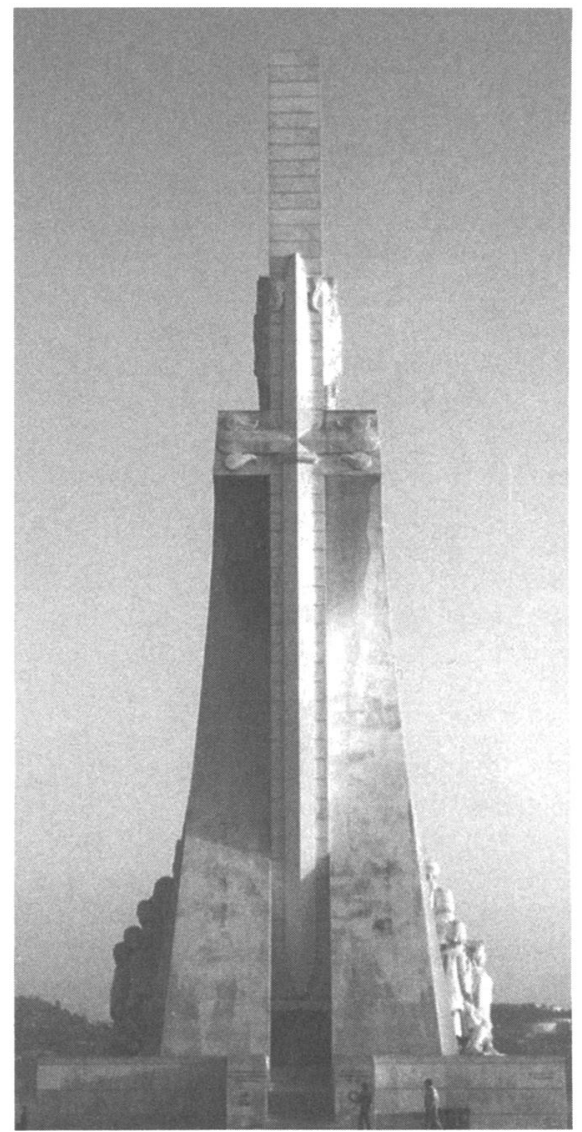

Fig. 2 The Padrão dos Descobrimentos photo E. W. Sapega.

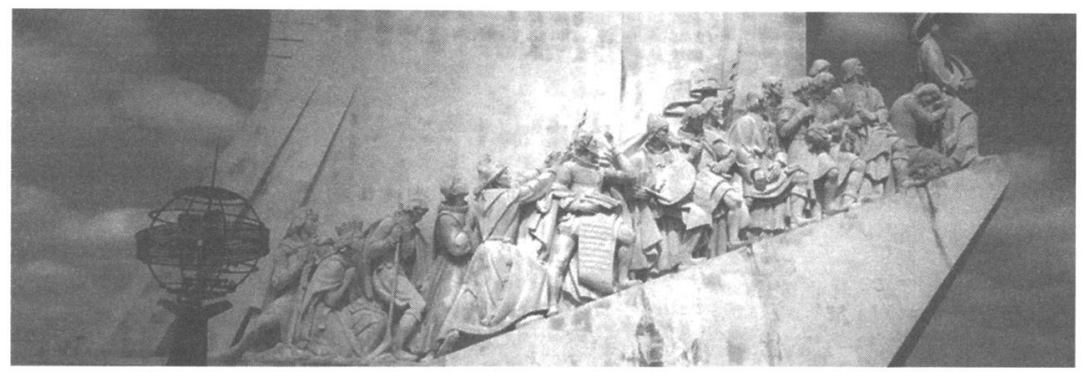

Fig. 3 The Padrão dos Descobrimentos photo A. E. Sapega. 


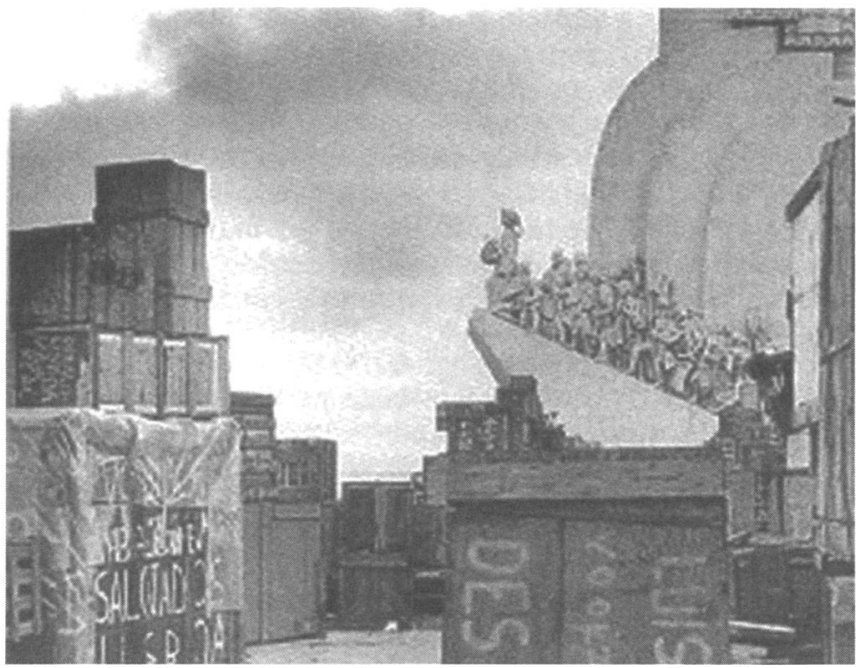

Fig. 4 The Padrão dos Descobrimentos in 1975 from Alfredo Cunha, Naquele Tempo (Lisboa: Contexto, 1995) 109.

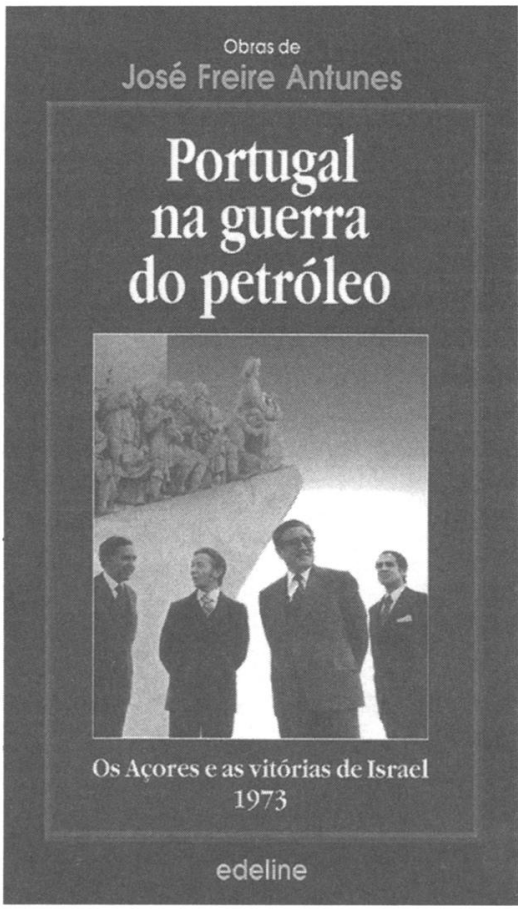

Fig. 5 Cover of José Freire Antunes, Portugal na guerra do petróleo (Carnaxide: Edline, 2000). 


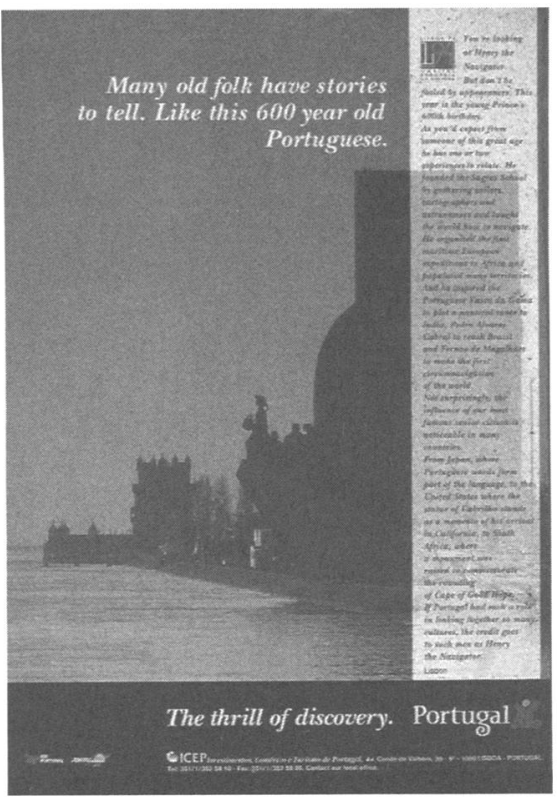

Fig. 6 Print advertisement "The thrill of discovery. Portugal," 1994 ICEP/Portugal.

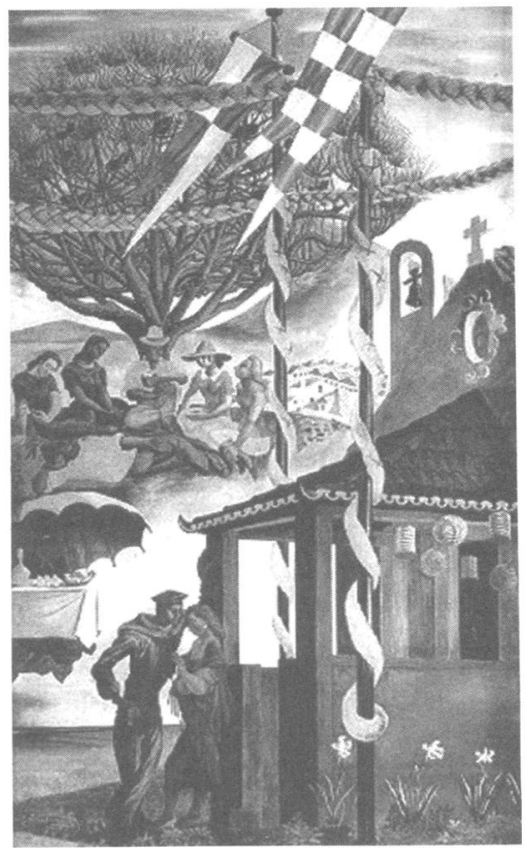

Fig. 7 José de Almada Negreiros, “Ó Terra Onde Eu Nasci," from Almada (Lisboa: Fundação Calouste Gulbenkian, 1985) 216. 


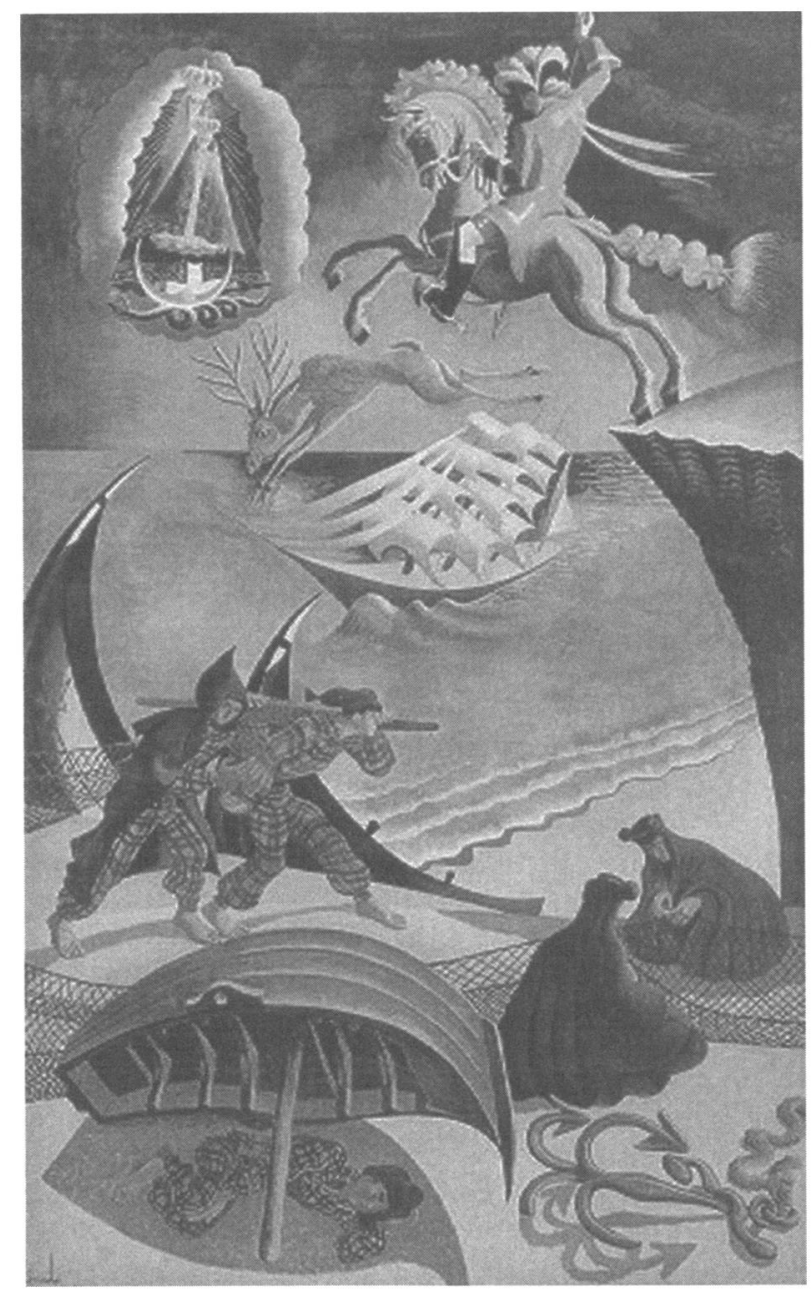

Fig. 8 José de Almada Negreiros, "Dom Fuas Roupinho 1. ${ }^{\circ}$ Almirante da Esquadra do Tejo," from Almada (Lisboa: Fundação Calouste Gulbenkian, 1985) 215. 


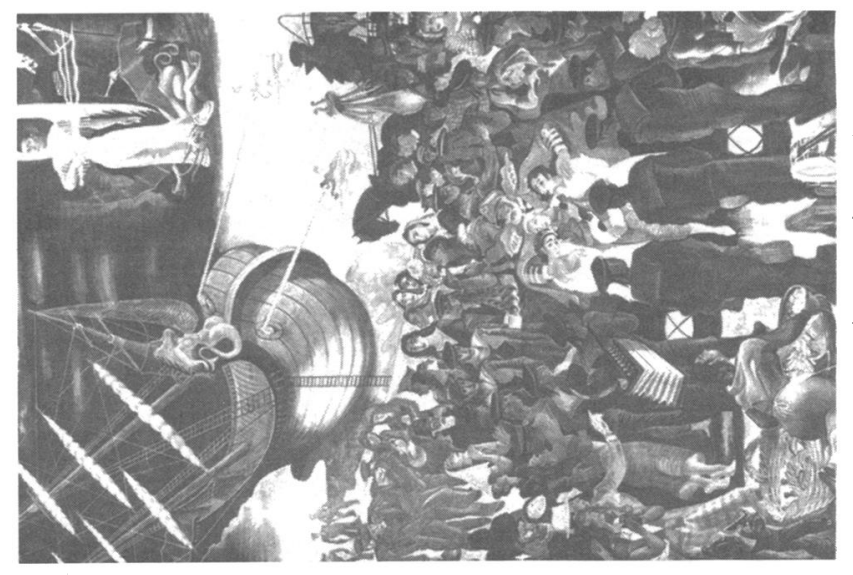

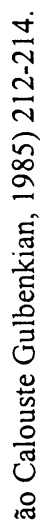

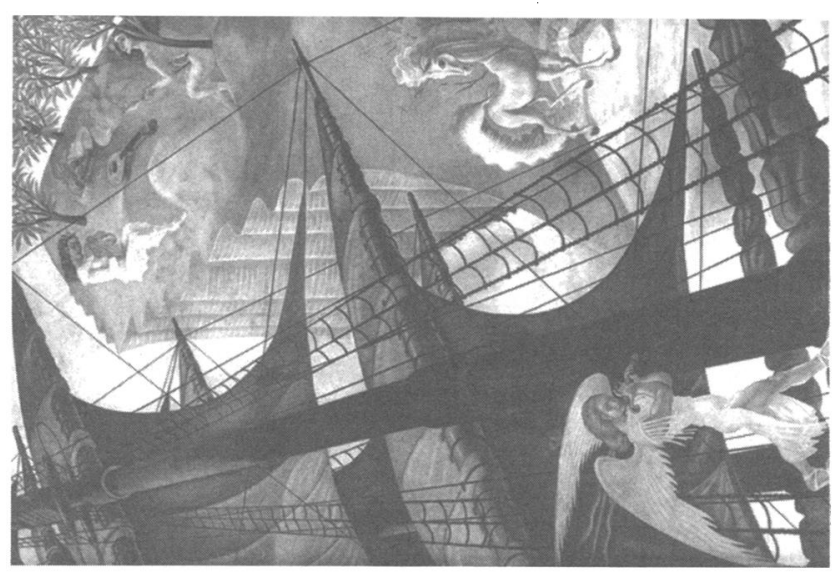

要

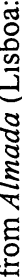

형

売

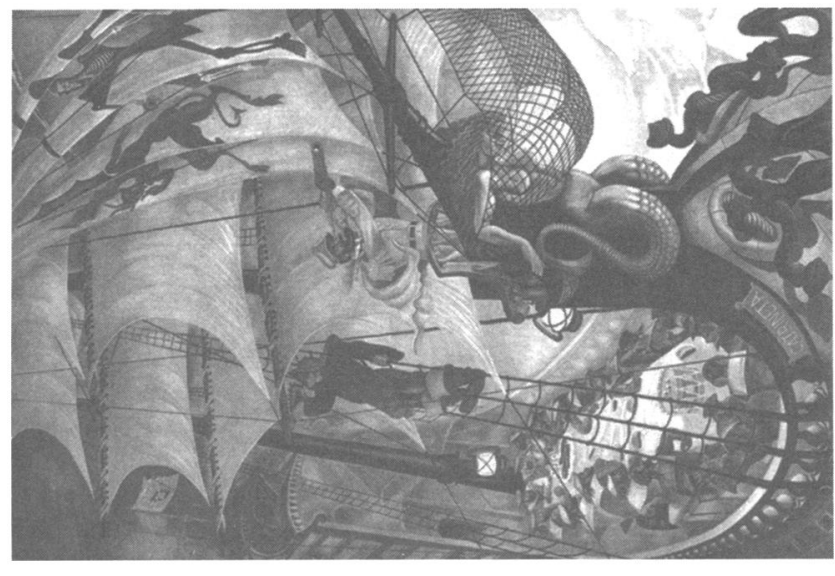

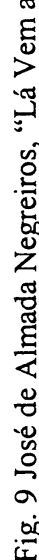




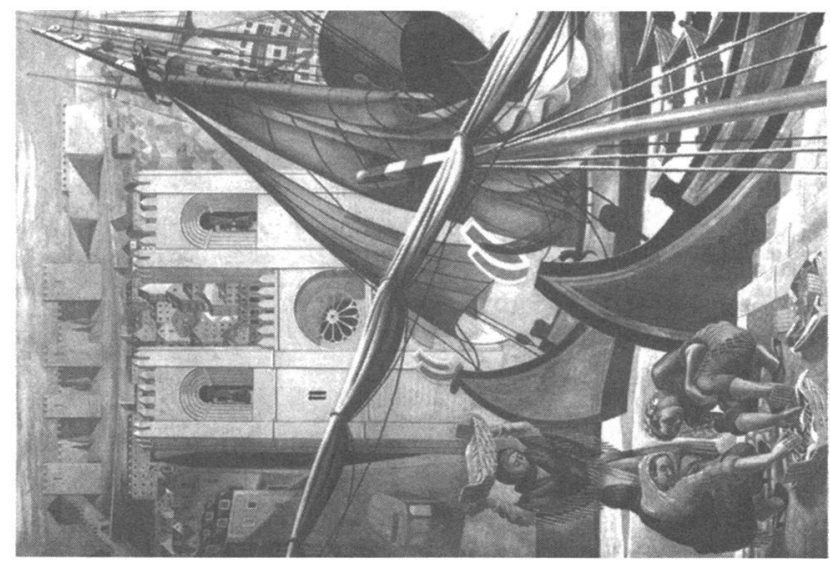

ㅇํㄹ
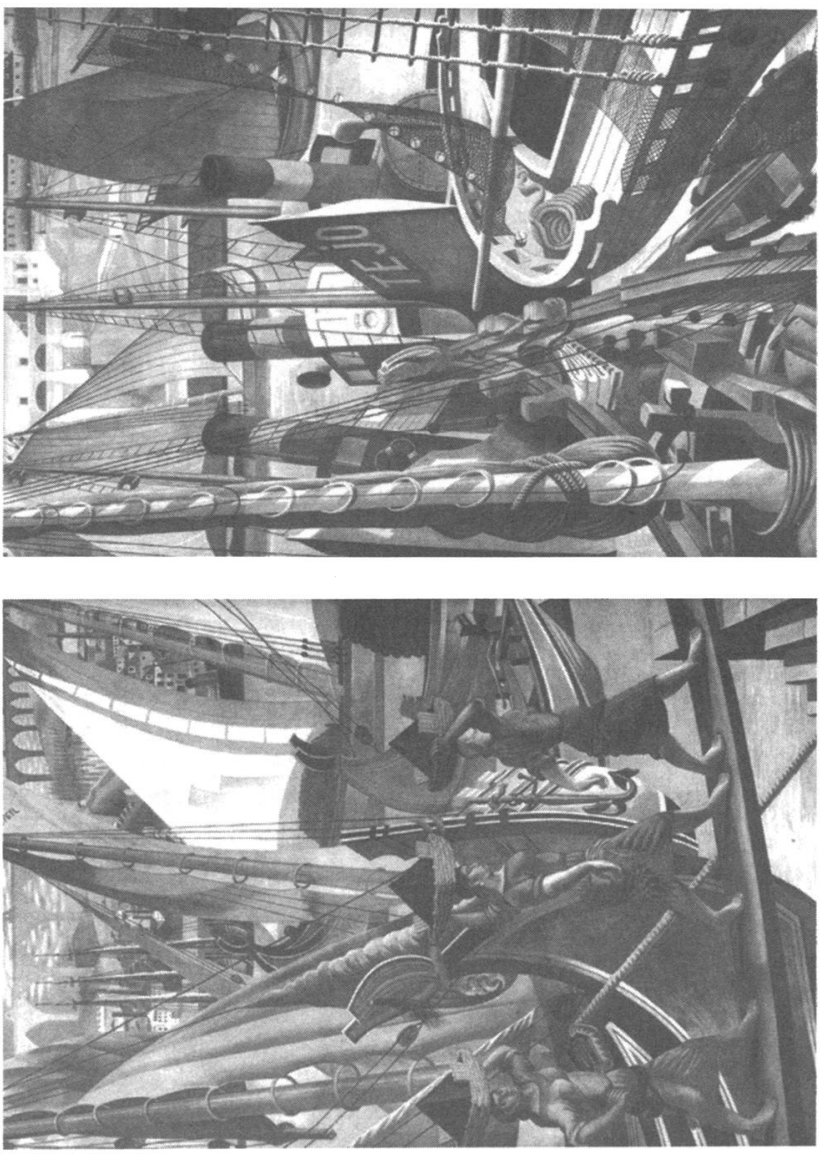

리

음

몽

Eิ

3

-

कิ สี

은

क

突高

Z

욤

른 음

ชั

ชั

怘 氶

으로

这 